\title{
Mathematical modelling for solar cell, panel and array for photovoltaic system
}

\author{
Hina N. Kadeval* \\ College of Renewable Energy \& Environmental Engineering, Sardarkrushinagar- 385506 \\ (Gujrat), India \\ V. K. Patel \\ U. V. Patel College of Engineering \& Technology, Ganpat University, Ganpat Vidyanagar, \\ Mehsana-384012 (Gujrat), India \\ ${ }^{*}$ Corresponding author. Email: hina_280@sdau.edu.in
}

\section{Article Info}

https://doi.org/10.31018/

jans.v13i3.2529

Received: February 15, 2021

Revised: August 8, 2021

Accepted: August 25, 2021

\section{How to Cite}

Kadeval, H. N. and Patel, V. K.. (2021). Mathematical modelling for solar cell, panel and array for photovoltaic system. Journal of Applied and Natural Science, 13(3), 937 - 943. https://doi.org/10.31018/jans.v13i3.2529

\begin{abstract}
Renewable energy is considered as next alternative to fossil fuels and nowadays, it attracts much attention in agriculture and environmental protection. Application of solar photovoltaic system is drying and dehydration of products, heating, irrigation, greenhouse and power generation etc. Temperature and sun radiation varies nonlinearly. Power generation varies with reference to radiation and temperature in photo-voltaic (PV) system. PV characteristic is nonlinear and PV cell is the basic unit for electricity generation. To get the characteristic response of $\mathrm{PV}$, it aimed to develop a solar cell/panel model and array on a platform like MATLAB. In this research paper, step by step procedure has been defined for modelling solar cell, panel, and array models of the photovoltaic system. Kyocera solar KC-200GT 200W solar panel is used as a reference model for further modelling. The PV array characteristic are simulated for different irradiance $\left(200 \mathrm{~W} / \mathrm{m}^{2}, 400 \mathrm{~W} /\right.$ $\left.\mathrm{m}^{2}, 600 \mathrm{~W} / \mathrm{m}^{2}, 800 \mathrm{~W} / \mathrm{m}^{2}, 1000 \mathrm{~W} / \mathrm{m}^{2}\right)$ and temperature variation $\left(25^{\circ} \mathrm{C}, 35^{\circ} \mathrm{C}, 45^{\circ} \mathrm{C}, 55^{\circ} \mathrm{C}, 75^{\circ} \mathrm{C}\right)$. The output characteristic of the reference model matches with simulated results. The output reduced when the solar irradiation reduced from 1000 to $200 \mathrm{~W} / \mathrm{m}^{2}$. As the temperature increased, the output voltage decreases, whereas the output current increases slightly. This model would be useful for investigating the effect of different parameters like series resistance, shunt resistance, thermal voltage, solar cell temperature coefficient of short circuit current etc. It would also be useful for investigating the working parameters like temperature \& radiation condition and different series and parallel combinations of panels. This modelling is useful in investigating the performance of solar arrays in different applications of solar power generation, as well as modelling provides a major role in the mounting of $\mathrm{PV}$ panels.
\end{abstract}

Keywords: Cell, Array, P-V, I-V, Temperature coefficient

\section{INTRODUCTION}

Non-Renewable sources are now depleting day by day, so renewable sources' utilisation is essential (Tummuru et al., 2015). Modelling of panel and array is being updated to enhance the panel performance and its application. A proposed model is based on solar cell and array's mathematical equations and built with common blocks in the Simulink environment(Tsai et al.,2008). Modelling and simulation of the panel, as well as array for characteristic evaluation and different parameters effect, can be analysed. (Natarajan et al., 2011). This paper presents a step-by-step method (Nguyen and Nguyen, 2015) for developing a solar cell/panel and array model for any defined physical parameter and different working conditions. This modelling has been done in MATLAB/Simulink environment.

\section{MATERIALS AND METHODS}

\section{Solar Cell Equivalent circuit}

\section{Cell modelling}

As shown in Fig.1, the equivalent circuit diagram was a solar cell "four parameters model" consisting of a diode, series resistance, parallel resistance, and current source (Umanand, 2007). The current source represented the light generated current of the solar cell, and a diode had a nonlinear impedance of the $p-n$ junction. The series resistance represents the internal electrical losses and shunt resistance corresponds to the leakage current to the ground (Esram and Chapman, 
2007). The diode was connected in anti parallel with the light generated current source represent the theoretical model of ideal solar cell.

$$
\mathrm{I}_{\mathrm{p}}=\mathrm{I}_{\mathrm{d}}+\mathrm{I}_{\mathrm{Rsh}}+\mathrm{I}
$$

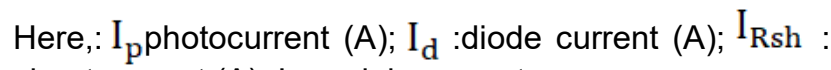
shunt current $(A)$; I; module current

$$
\begin{aligned}
& \mathrm{I}=\mathrm{I}_{\mathrm{p}}-\mathrm{I}_{\mathrm{d}}-\left(\frac{\mathrm{V}+\mathrm{I}_{\mathrm{Rs}}}{\mathrm{R}_{\mathrm{sh}}}\right) \\
& \mathrm{I}_{\mathrm{d}}=\mathrm{I}_{0}\left[\left(\exp \left(\frac{\mathrm{q}(\mathrm{V}+\mathrm{IRs})}{\mathrm{nKNsT}}\right)-1\right)\right]
\end{aligned}
$$

Here $I_{d}$ :diode current $(A) ; I_{0}=$ reverse saturation cur rent; $V_{\mathrm{T}}=$ Volt equivalent temp $=\mathrm{kT} / \mathrm{q} ; \mathrm{n}=2$ for silicon

$$
\begin{aligned}
& \mathrm{I}_{0}=\mathrm{I}_{\mathrm{rs}}\left(\frac{\mathrm{T}}{\mathrm{Tr}}\right)^{3}\left[\exp \left[\frac{\mathrm{qEg} 0\left(\frac{1}{\mathrm{Tr}}-\frac{1}{\mathrm{~T}}\right)}{\mathrm{nK}}\right]\right] \\
& \mathrm{Irs}=\frac{I s c}{\left(\exp \left(\frac{q V o c}{n N s K T}\right)_{-1}\right)}
\end{aligned}
$$

$\mathrm{V}_{\mathrm{T}}=$ Volt equivalent temp $=\mathrm{kT} / \mathrm{q}$; where $\mathrm{q}=$ $1.60217646 \times 10^{-19} \mathrm{C}, \mathrm{n}=$ ideality factor $=1.3$; $\mathrm{K}=$ Boltzmann's constant $1.3806503 \times 10^{-23} \mathrm{~J} / \mathrm{K} ; \mathrm{Eg} 0$ band gap enery in $\mathrm{eV}=1.1 \mathrm{eV}$

$$
\mathrm{I}=\left[\mathrm{I}_{\mathrm{p}}-\mathrm{I}_{0}\left[\exp \left(\frac{(\mathrm{q}(\mathrm{V}+\mathrm{IRs})}{\mathrm{n} \mathrm{KNs} \mathrm{T}}\right)-1\right]-\left(\frac{\mathrm{V}+\mathrm{IR}_{\mathrm{s}}}{\mathrm{R}_{\mathrm{sh}}}\right)\right]
$$

This expression depicts the relation between voltage and current of a photovoltaic module. The mathematical equation (5) is a nonlinear equation(Habbati et al.,2014). PV cells are combined on a large scale called modules (also known as panels), and modules combined together on a large scale are known as PV arrays. A combination of series and parallel modules can give desired output voltage and current from the array. The equivalent circuit for the solar cells/panel arranged in parallel and series as shown in Fig. 2.

Mathematical model as per Eq. (7) is relationship between solar array voltage and solar array current

$$
\mathrm{I}_{\mathrm{A}}=\mathrm{N}_{\mathrm{P}} \mathrm{I}_{\mathrm{ph}}-\mathrm{N}_{\mathrm{P}} \mathrm{IO}\left[\exp \left(\frac{\mathrm{q}\left(\frac{\mathrm{V}}{\mathrm{Ns}}+\mathrm{I} \frac{\mathrm{Rs}}{\mathrm{Np}}\right)}{\mathrm{nKT}}\right)-1\right]-\frac{\mathrm{V}\left(\frac{\mathrm{N}_{\mathrm{p}}}{\mathrm{N}_{\mathrm{s}}}\right)+\mathrm{I} * \mathrm{R}_{\mathrm{s}}}{\mathrm{R}_{\mathrm{sh}}}
$$

$\mathrm{I}_{\mathrm{A}}$ : PV array output current, in $\mathrm{A} ; \mathrm{V}_{\mathrm{A}}$ : $\mathrm{PV}$ array output voltage, in $V ; I_{P h}$ : Solar cell photocurrent, in $A ; I_{0}$ : Saturation current of diode $A ; n$ : Solar cell diode $P-N$ junc-

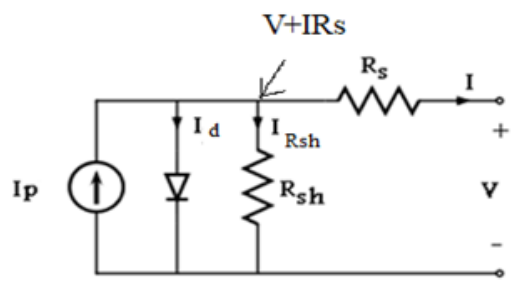

Fig. 1. solar cell model (Xuan et al., 2015). tion ideality factor $=1.3$, between 1 and 5 (dimensionless); $R_{S}$ : Cell intrinsic series resistance, in $\Omega$; $R_{\mathrm{P}}$ : Cell intrinsic shunt or parallel resistance, in $\Omega$; $\mathrm{V}_{T h}$ : Cell thermal voltage, in $\mathrm{V}$, determined as $\mathrm{V}_{\mathrm{Th}}=\mathrm{k}$ $\mathrm{T}_{\mathrm{C}} / \mathrm{q} ; \mathrm{k}$ : Boltzmann's constant, $1.38065810^{-23} \mathrm{~J} / \mathrm{K} ; \mathrm{T}$ : Solar cell absolute operating temperature, in K; q: Electron charge, $1.6021773310^{-19} \mathrm{Cb} ; \mathrm{N}_{\mathrm{P}}$-parallel connected modules and $\mathrm{N}_{\mathrm{S}}$-series connected modules

\section{Input parameter for Solar Panel modelling}

1. Ki (Solar cell temperature coefficient of short-circuit current- $\mathbf{0 . 0 0 3 2} \mathrm{A} /$ module/diff. temp

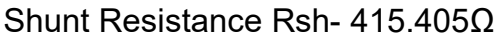

Series Resistance Rs - $0.221 \Omega$

Short circuit current Isc $-8.21 \mathrm{~A}$

Maximum power Pm-200.143W

Maximum PV module voltage $\mathrm{Vm}-26.4 \mathrm{~V}$

Maximum PV module Current Im-7.58A

Open circuit voltage $=32.9 \mathrm{~V}$

Energy band gap $-1.1 \mathrm{eV}$

Cell ideality factor $=1.3$

10. Charge of electron $1.60217646 \times 10^{-19} \mathrm{C}$

11.Operating temperature $\mathrm{T}-\left({ }^{\circ} \mathrm{C}+273\right)$

12.Reference temperature $\mathrm{Tr}-298^{\circ} \mathrm{K}$

13. Parallel cell $(\mathrm{Np})=01$

14. Series cell $(\mathrm{Ns})=54$

\section{Input parameter for Array Modelling}

10x3 Solar Panel (Kyocera Solar Panel Kc200GT200W)

Array Specification at $1000 \mathrm{~W} / \mathrm{m}^{2}, 25^{\circ} \mathrm{C}$

1.Series connected module-10

2.Parallel connected module-03

3.Peak Power-6000W

4. Maximum $P V$ array voltage $\mathrm{Vm}-264 \mathrm{~V}$

5.Maximum PV array Current Im-22.83A

6.Open circuit voltage-329V

7.Short circuit current -24.63A

\section{Step by step procedure for Array modelling in MATLAB}

A basic block schematic for solar cell modelling is shown in Fig. 3 to model solar cells in terms of the current equation. Input parameters are listed in section 2.2. Different solar cell parameters like open circuit voltage, short circuit current, voltage rating, current rating,

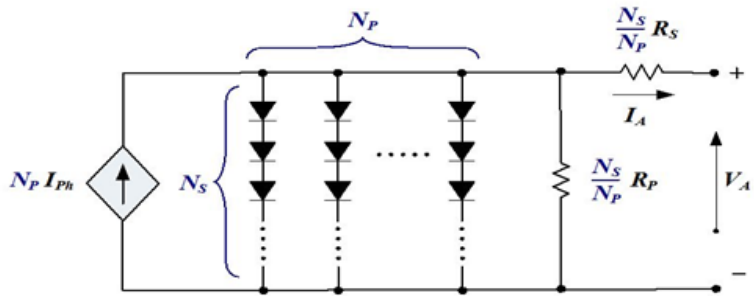

Fig. 2. Equivalent circuit for solar cell grouped in larger units (Marcelo et.al., 2016). 
series resistance, shunt resistance etc. After parameter listing the solar cell, the first step is to model photo current generated by one single solar cell as per step1. The second step is to model the shunt current flowing through shunt resistance (Rsh). It is modelled according to step 2. The third step is to model the series current, which flows through the series resistance (Rs) and is modelled according to step 3 . The fourth step is to model the reverse saturation current, which is flowing through the diode and modelled as per step 4 . Total module current can be depicted in step 5 . In the fifth step, all currents are added together from steps 1 to 4 , which is solar current through a single solar cell. The same model is used for solar modules and arrays for generation of IV and PV curves through solar arrays is done in MATLAB. This model is general and dynamic for any solar cell, panel and array.

\section{Step 1: Modelling of i_ph(Module photocurrent)}

Initially, in system block, degree Celsius temperature (operating temperature) was converted into degree Kelvin and then given to subsystem.

$$
\mathrm{I}_{\mathrm{ph}}=\left[\mathrm{I}_{\mathrm{sc}}+\mathrm{K}_{\mathrm{i}}(\mathrm{T}-298)\right] * \frac{\mathrm{I}_{\mathrm{r}}}{1000}
$$

As per Eq.7, i_ph was photocurrent and modelled in MATLAB as shown below where its subsystem was also shown and all parameters were defined say i_ph (photo current), isc (short circuit current of module), Ki (Solar cell temperature coefficient of the short-circuit current (A/module/diff. temp (in ${ }^{\circ} \mathrm{K}$ or $\left.{ }^{\circ} \mathrm{C}\right)$ ), $\mathrm{T}$ (operating temperature), Ir (solar irradiance). Modeling was shown in Fig.4.

\section{Step 2 : Modelling of i_sh (Module shunt saturation current)}

Module shunt saturation current was modeled in MATLAB as shown in Fig.5.

As per Eq.8, where $\mathrm{N}_{\mathrm{p}}$ and $\mathrm{N}_{\mathrm{s}}$ value were given for panel and array modeling and $\mathrm{V}$ was open circuit voltage so it was same as Voc say $32.9 \mathrm{~V}$ and $R_{\mathrm{S}}$ and $R_{\mathrm{sh}}$ represent the series and parallel resistances of the cell.

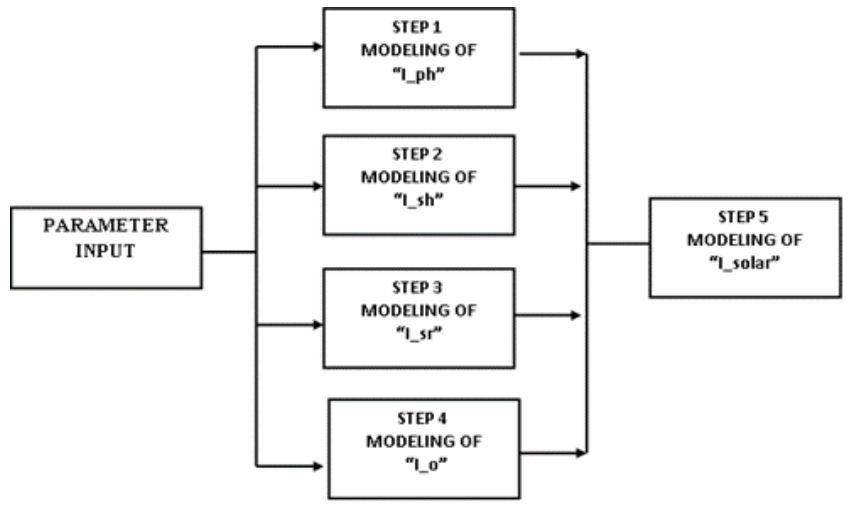

Fig. 3. Solar Cell modeling block schematic (Xaun et.al. 2015).
Photo Current (Iph)

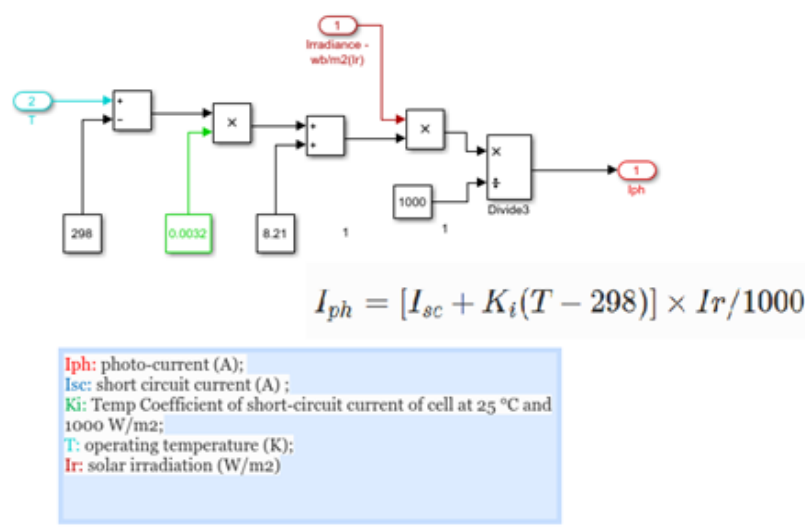

Fig. 4. Modeling of Module photo current i_ph.

Module Shunt Current (Ish)

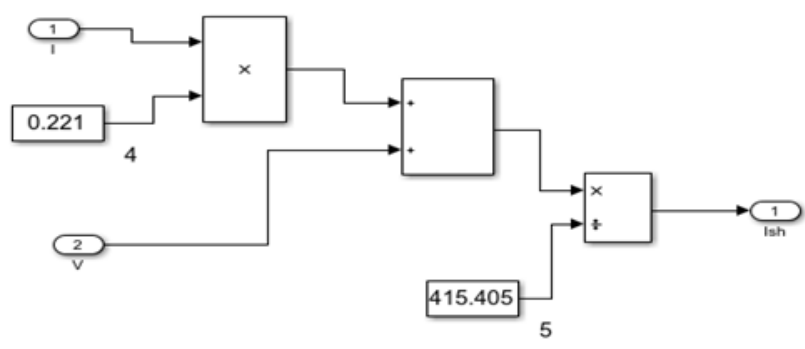

$\mathrm{Ish}=(\mathrm{V}+\mathrm{IRs}) / \mathrm{Rsh}$

Fig. 5. Modelling of Module shunt saturation current.

Modeling was very simple just using adder, multiplier and divider blocks.

$\mathrm{I}_{\mathrm{sh}}=\frac{\mathrm{V}\left(\frac{\mathrm{N}_{\mathrm{p}}}{\mathrm{N}_{\mathrm{s}}}\right)+\mathrm{I} * \mathrm{R}_{\mathrm{s}}}{\mathrm{R}_{\mathrm{sh}}}$

\section{Step 3 : Modeling of i_rs (Module reverse saturation current)}

Module reverse saturation current was modelled in MATLAB as shown in Fig. 6 as per Eq.9 where different constants are taken as k: Boltzmann's constant $1.380658 \times 10^{-23} \mathrm{~J} / \mathrm{K}$ q: electron charge $1.60217733 \times 10^{-}$ ${ }^{19} \mathrm{C}$, etc.

$$
\mathrm{I}_{\mathrm{rs}}=\mathrm{I}_{\mathrm{sc}} /\left[\exp \left(\frac{\mathrm{qv}_{\mathrm{oc}}}{\mathrm{N}_{\mathrm{s}} \mathrm{knT}}\right)-1\right]
$$

Step 4 : Modeling of i_o (Module saturation current)

Modeling of module saturation current was modeled in MATLAB as shown in Fig.7

$$
\mathrm{I}_{\mathrm{o}}=\mathrm{I}_{\mathrm{rs}}\left[\frac{\mathrm{T}}{\mathrm{T}_{\mathrm{r}}}\right]^{3} \exp \left[\frac{\mathrm{q} * \mathrm{E}_{\mathrm{go}}}{\mathrm{nk}}\left(\frac{1}{\mathrm{~T}}-\frac{1}{\mathrm{~T}_{\mathrm{r}}}\right)\right]
$$

Modelling of saturation current was done as per Eq.10, whose parameters were i_rs: Module reverse saturation current; $\mathrm{T}_{\mathrm{R}}$ : Solar cell absolute reference tempera- 


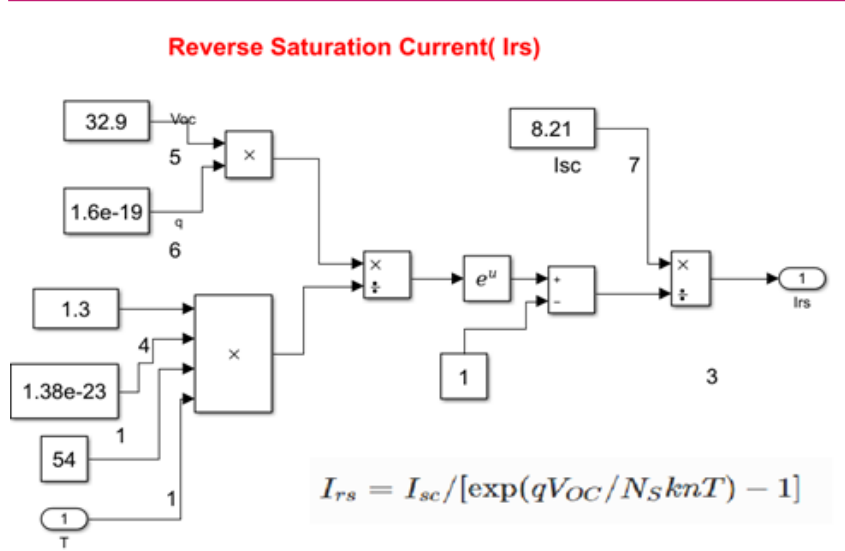

Fig. 6. Modeling of module reverse saturation current i_rs. ture at STC, in $\mathrm{K}$; $\mathrm{T}$ : absolute operating temperature of solar cell, in K; q: Electron charge, 1.60217733e-19 Cb; k Boltzmann's constant; $1.3806503 \times 10^{-23} \mathrm{~J} / \mathrm{K}$ and $\mathrm{n}$ the ideality factor Modified.

\section{Step 5 : Modelling of I(Module output current)}

The modellin of module output current is given in Fig.8a.

\section{Complete simulation model with step 1 to step 5}

Step 1 to step 4 was done and combine together in step 5 as per Eq.11 complete block schematic is shown in Fig.8(b).

$$
\mathrm{I}=\mathrm{N}_{\mathrm{p}} * \mathrm{I}_{\mathrm{ph}}-\mathrm{N}_{\mathrm{p}} * \mathrm{I}_{0} *\left[\exp \left(\frac{\frac{\mathrm{V}}{\mathrm{N}_{\mathrm{S}}}+\mathrm{I} * \frac{\mathrm{R}_{\mathrm{S}}}{\mathrm{N}_{\mathrm{p}}}}{\mathrm{nV} \mathrm{v}_{\mathrm{t}}}\right)-1\right]-\mathrm{I}_{\mathrm{sh}}
$$

\section{Simulation results for IV and PV curve of solar PV module and PV system}

Simulation results shown I-V characteristic and $\mathrm{P}-\mathrm{V}$ characteristic of solar module having $\mathrm{Voc}=32.9 \mathrm{~V}$ and module current of $I s c=8.21 \mathrm{~A}$ with different irradiance say $200 \mathrm{~W} / \mathrm{m}^{2}, 400 \mathrm{~W} / \mathrm{m}^{2}, 600 \mathrm{~W} / \mathrm{m}^{2}, 800 \mathrm{~W} / \mathrm{m}^{2}, 1000 \mathrm{~W} /$ $\mathrm{m}^{2}$ and different temperature say $25^{\circ} \mathrm{C}, 35^{\circ} \mathrm{C}, 45^{\circ} \mathrm{C} 55^{\circ}$ C, $75^{\circ} \mathrm{C}$. I-V \& P-V characteristic was shown in Fig. 9 \& 10.

Solar module I-V characteristic at different irradiance of

Module output Current (I)

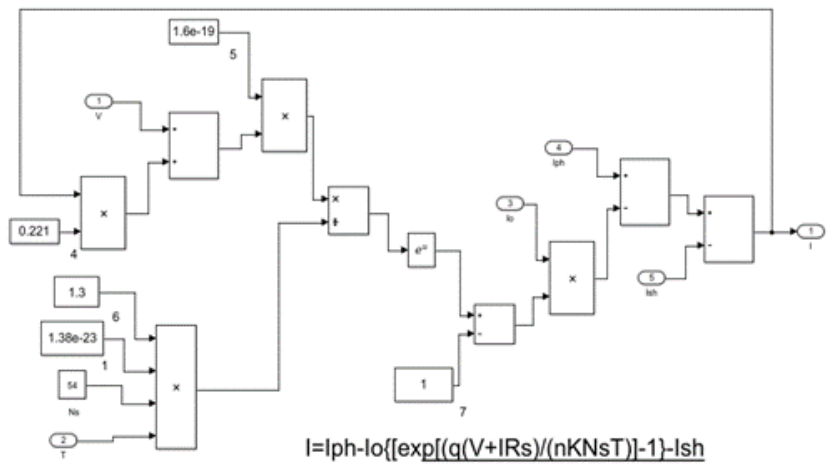

Fig. 8(a). Modeling of module output current.

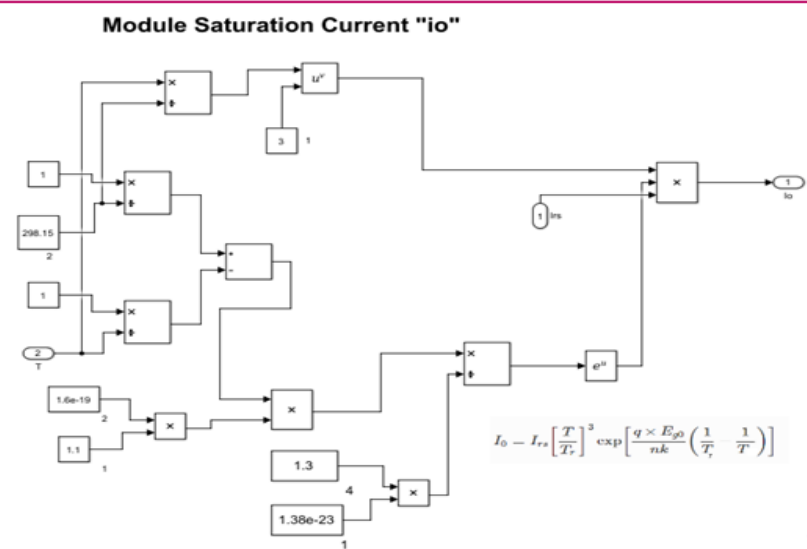

Fig. 7. Modeling of $i_{-}$o (Module saturation current).

$200 \mathrm{~W} / \mathrm{m}^{2}, 400 \mathrm{~W} / \mathrm{m}^{2}, 600 \mathrm{~W} / \mathrm{m}^{2}, 800 \mathrm{~W} / \mathrm{m}^{2}, 1000 \mathrm{~W} / \mathrm{m}^{2}$ is shown in Fig.9(a) with peak point value of voltage and current say $8.20 \mathrm{~A}, 32.89 \mathrm{Vat} 1000 \mathrm{~W} / \mathrm{m}^{2}$

Solar module I-V characteristics at different temperatures say $25^{\circ} \mathrm{C}, 35^{\circ} \mathrm{C}, 45^{\circ} \mathrm{C} 55^{\circ} \mathrm{C}, 75^{\circ} \mathrm{C}$ is shown in Fig.9(b), which shows Voc voltage is reduced from $32.89 \mathrm{~V}$ to $24.19 \mathrm{~V}$ as temperature increases. Solar module $\mathrm{P}-\mathrm{V}$ characteristic at different irradiance say $200 \mathrm{~W} /$ $\mathrm{m}^{2}, 400 \mathrm{~W} / \mathrm{m}^{2}, 600 \mathrm{~W} / \mathrm{m}^{2}, 800 \mathrm{~W} / \mathrm{m}^{2}, 1000 \mathrm{~W} / \mathrm{m}^{2}$ was shown in fig.10(a), which shown with different peak power point in graph say $200 \mathrm{~W}$ to $34.73 \mathrm{~W}$ Solar mod-
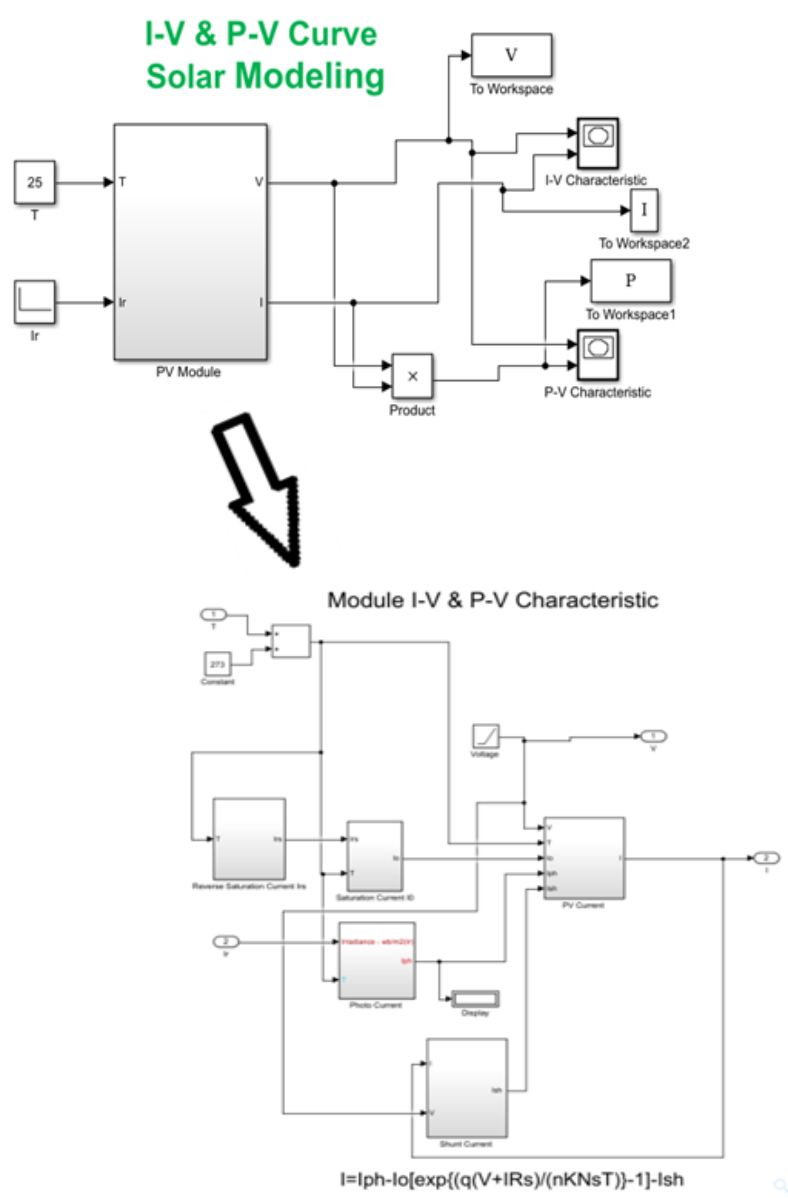

Fig. 8(b). Solar panel modeling for IV and PV curve. 


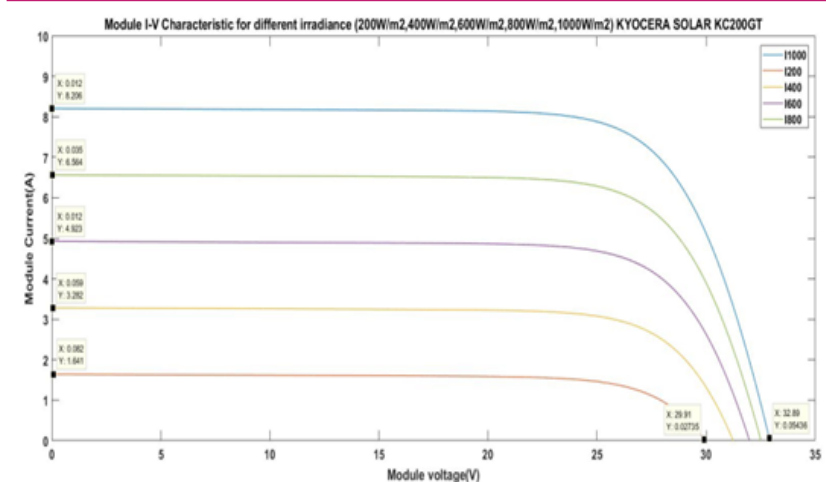

Fig. 9(a). I-V characteristic of solar module with different irradi-

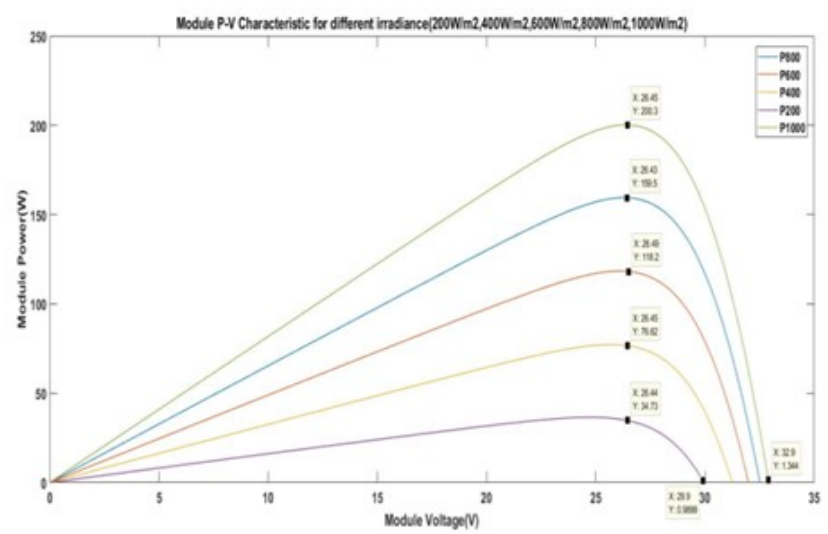

Fig.10(a). P-V characteristic of solar module with different irradiance.

ule P-V characteristic at different temperature say $25^{\circ}$ C, $35^{\circ} \mathrm{C}, 45^{\circ} \mathrm{C} 55^{\circ} \mathrm{C}, 75^{\circ} \mathrm{C}$. are plotted as shown in Fig.10(b), which shows the Voc voltages reduces from $32.91 \mathrm{~V}$ to $24.21 \mathrm{~V} t$ as temperature increases.

Now solar panel model is used for arrays. So now generated characteristic is referred to as system I-V and P$\mathrm{V}$ characteristic which is shown as below Fig.11 and 12.

Solar system modelling is done by connecting 10 series modules and 03 parallel modules of panel I-V characteristic is generated as shown in Fig.11(a) for different irradiance say $200 \mathrm{~W} / \mathrm{m}^{2}, 400 \mathrm{~W} / \mathrm{m}^{2}, 600 \mathrm{~W} / \mathrm{m}^{2}, 800 \mathrm{~W} /$ $\mathrm{m}^{2}, 1000 \mathrm{~W} / \mathrm{m}^{2}$

Solar system I-V characteristic for different temperature say $25^{\circ} \mathrm{C}, 35^{\circ} \mathrm{C}, 45^{\circ} \mathrm{C} 55^{\circ} \mathrm{C}, 75^{\circ} \mathrm{C}$ are plotted as shown in Fig.11(b), where system voltage reduces from 329V to $308.7 \mathrm{~V}$ as temperature increases.Solar system $\mathrm{P}-\mathrm{V}$ characteristic for different irradiance say $200 \mathrm{~W} / \mathrm{m}^{2}$, $400 \mathrm{~W} / \mathrm{m}^{2}, 600 \mathrm{~W} / \mathrm{m}^{2}, 800 \mathrm{~W} / \mathrm{m}^{2}, 1000 \mathrm{~W} / \mathrm{m}^{2}$ were plotted as shown in Fig.12(a) and peak power is $200 \mathrm{~W}$ to 34.71W

Solar system P-V characteristic for different temperature are plotted at $25^{\circ} \mathrm{C}, 35^{\circ} \mathrm{C}, 45^{\circ} \mathrm{C} 55^{\circ} \mathrm{C}, 75^{\circ} \mathrm{C}$ as shown in Fig.12(b)

Solar panel/array had variation with respect to change in series resistance(Rs) and shunt resistance(Rsh),

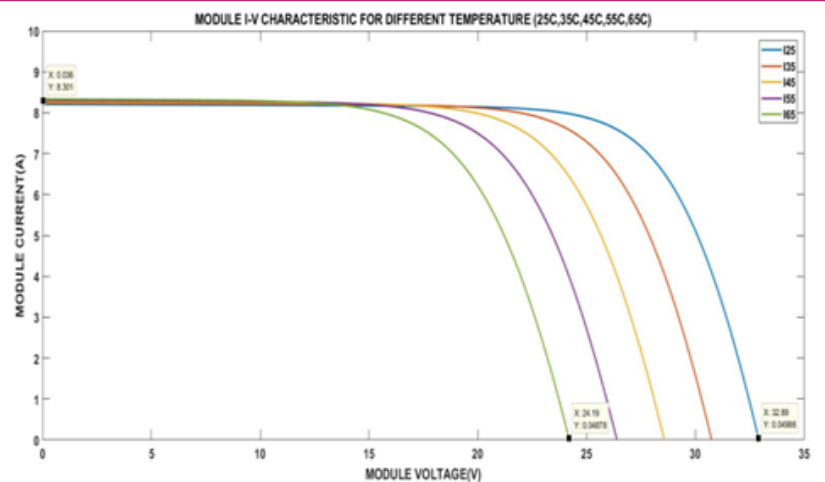

Fig. 9(b). I-V characteristic of solar module with different temperature.

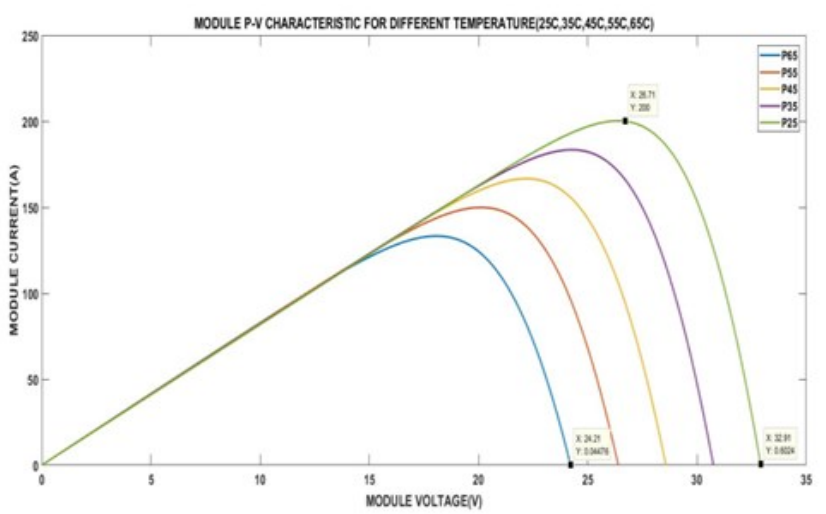

Fig.10(b). P-V characteristic of solar module with different temperature.

which are plotted as I-V curve for different irradiance condition

The datasheet Fig.13(a) \& 13(b) show IV characteristic of the solar panel of 200Wp (Kyocera solar KC200GT), which is used for further modelling with $\mathrm{Voc}=32.9 \mathrm{~V}$ and Isc=8.21A. Panel characteristic matches the same results with the datasheet for different irradiance and temperature condition. Which shows the validation of the mathematical model and its simulation results. From the datasheet efficiency of the panel is $16 \%$, where simulation results show the efficiency as near $15.76 \%$

\section{RESULTS AND DISCUSSION}

(i) $\mathrm{I}-\mathrm{V}$ and $\mathrm{P}-\mathrm{V}$ characteristics for solar panel under varying irradiation of $200 \mathrm{~W} / \mathrm{m}^{2}, 400 \mathrm{~W} / \mathrm{m}^{2}, 600 \mathrm{~W} / \mathrm{m}^{2}$, $800 \mathrm{~W} / \mathrm{m}^{2}, 1000 \mathrm{~W} / \mathrm{m}^{2}$ with constant temperature say $25^{\circ} \mathrm{C}$ are given in Fig.9(a) and Fig.10 (a).Whenirradiance increased then output currentincreased.

(ii) $\mathrm{I}-\mathrm{V}$ and $\mathrm{P}-\mathrm{V}$ characteristics for the solar panel under variable temperature and fix irradiation are obtained as in Fig.9(b) and Fig.10(b). here temperature variations are $25^{\circ} \mathrm{C}, 35^{\circ} \mathrm{C}, 45^{\circ} \mathrm{C} 55^{\circ} \mathrm{C}, 75^{\circ} \mathrm{C}$ at $1000 \mathrm{~W} / \mathrm{m}^{2}$ irradiance. 
(iii) I-V and P-V characteristics for solar array under var- (v) I-V characteristics for different series resistance and ying irradiation of $200 \mathrm{~W} / \mathrm{m}^{2}, 400 \mathrm{~W} / \mathrm{m}^{2}, 600 \mathrm{~W} / \mathrm{m}^{2}, 800 \mathrm{~W} /$ shunt resistance are shown in Fig.14(a) \& Fig.14(b).

$\mathrm{m}^{2}, 1000 \mathrm{~W} / \mathrm{m}^{2}$ with constant temperature say $25^{\circ} \mathrm{C}$ are The output characteristic curves of the model match the given in Fig.11(a) and Fig.12(a).When irradiance increas- characteristic of the Kyocera solar KC 200GT solar es then power output increases under operating condi- panel array of $10 \times 3$, whose results are verified as per tion. earlier study reference (Motan et al., 2018) and (iv) I-V and P-V characteristics for a solar array under datasheet of multicrystal $200 \mathrm{Wp}$ solar module. The varying temperature and constant irradiation is obtained simulation results are validated against the datasheet as in Fig.11(b) and Fig.12(b). Here temperature varia- of the photovoltaic module. In the cited reference systions are $25^{\circ} \mathrm{C}, 35^{\circ} \mathrm{C}, 45^{\circ} \mathrm{C} 55^{\circ} \mathrm{C}, 75^{\circ} \mathrm{Cat} 1000 \mathrm{~W} / \mathrm{m}^{2}$ irra- tem is also $6 \mathrm{~kW}$, which is configured by $2 \mathrm{PV}$ strings diance.

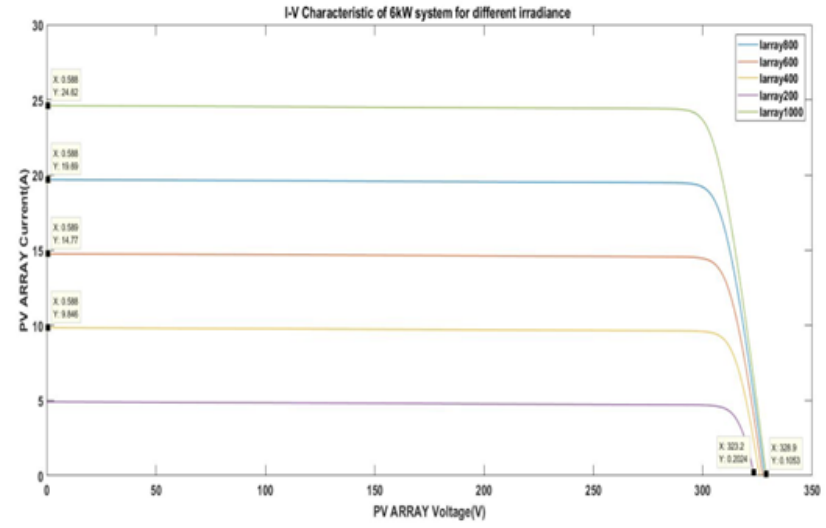
such that each of them consists of 15 series-connected

Fig. 11(a). I-V characteristic of solar system Modelling with different irradiance.

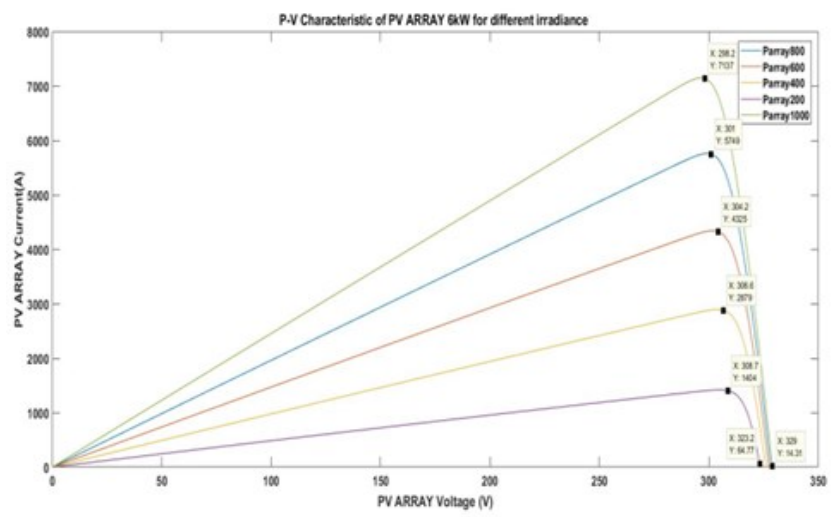

Fig. 12(a). P-V characteristic of solar system modeling

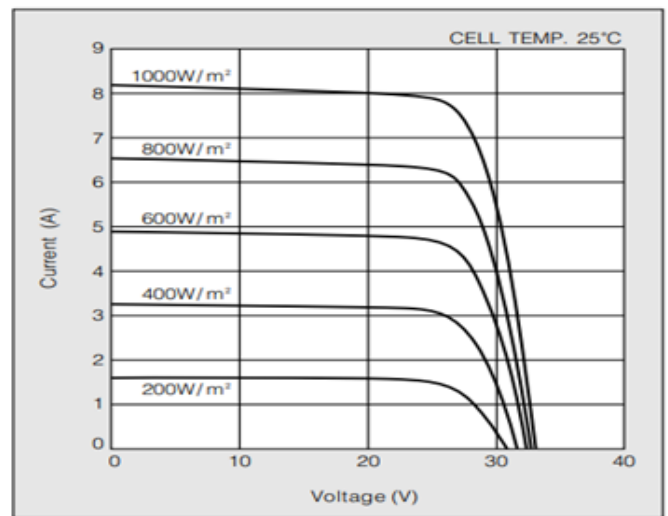

with

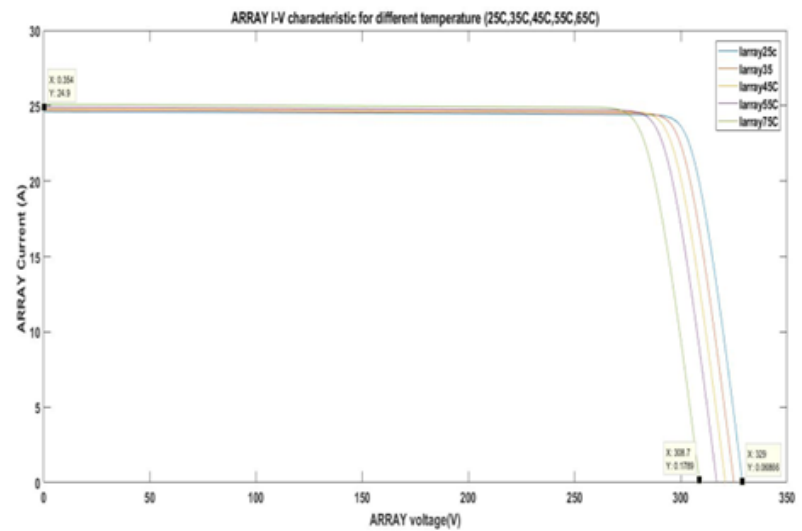

Fig. 11(b). I-V characteristic of solar system Modeling with different temperature.

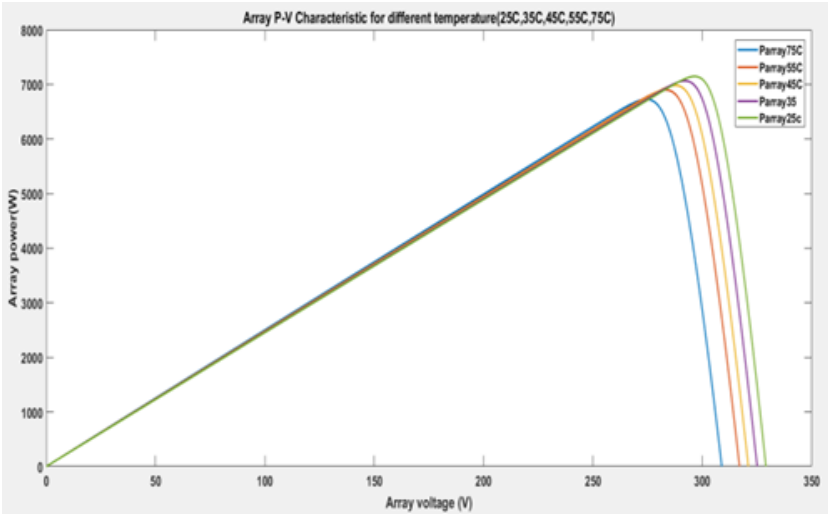

Fig. 12(b). P-V characteristic of solar system modeling

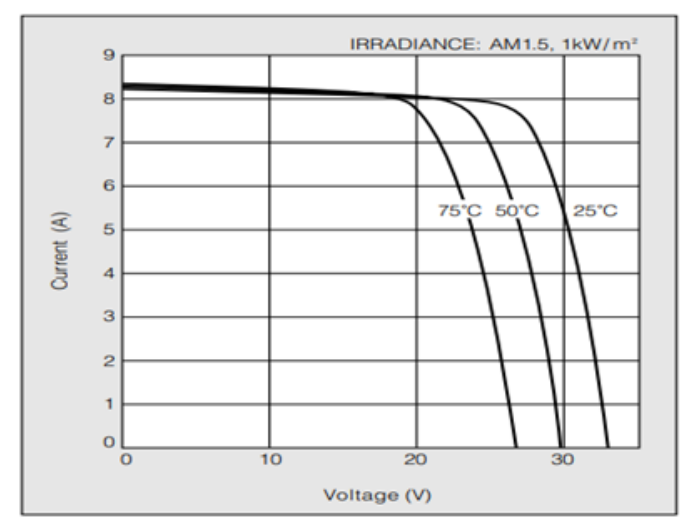

Fig. 13 (a). IV characteristic of solar panel 200Wp (Kyocera solar KC 200GT) at different irradiance (from datasheet).

Fig. 13(b). PV characteristic of solar panel 200Wp (Kyocera solar KC 200GT) at different temperature (from datasheet). 


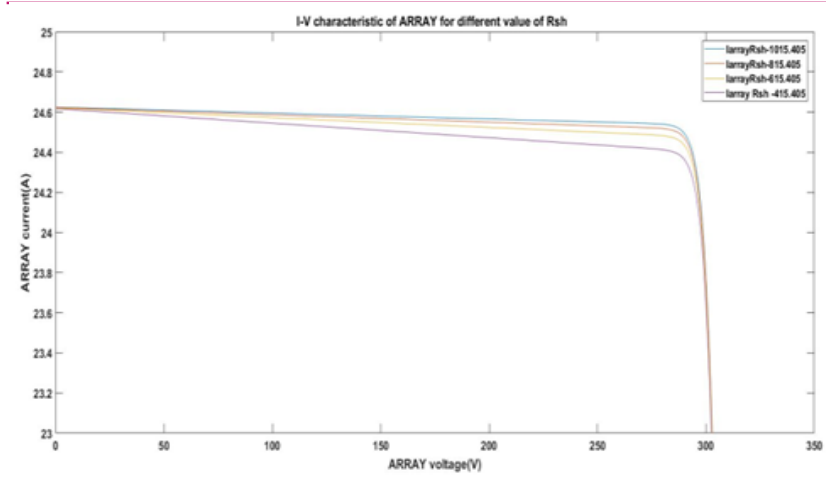

Fig. 14(a). I-V characteristic of PV array for different value of shunt resistance.

modules, while in this modelling, the present study has taken $10 \times 3$ modules (10 modules are in series and such 3 strings are in parallel) whose input parameters are listed above as Input parameter for Array Modelling. This modelling can be used for further modelling and prediction of system behaviour for power generation applications.

This MATLAB/Simulink model is a dynamic model for any solar panel and array modelling. This modelling helps to understand the the I-V and $\mathrm{P}-\mathrm{V}$ operating principles and tool for predicting the behaviour of PV panel and array under any variable environmental condition as well as variable parameters like series resistance, shunt resistance, ideality factor, operating temperature etc. This mathematical modelling has been verified with results available from datasheet of Kyocera (2009).

\section{Conclusion}

Stepwise procedure for modelling solar panel and array in MATLAB with user-friendly stimulation tool is shown in each step, which will help further modelling the solar system and I-V \& P-V characteristic. So that any system behaviour can be predicted for any number of cell, panel, or array under any variable of environmental condition like temperature, irradiance, series resistance, shunt resistance, etc. The present model is the dynamic model for further modelling solar PV systems using the maximum power point tracking technique and its performance analysis for power generation application in a solar PV system.

\section{Conflict of interest}

The authors declare that they have no conflict of interest.

\section{REFERENCES}

1. Esram T. \&Chapman P.L.(2007), Comparison of Photovol-

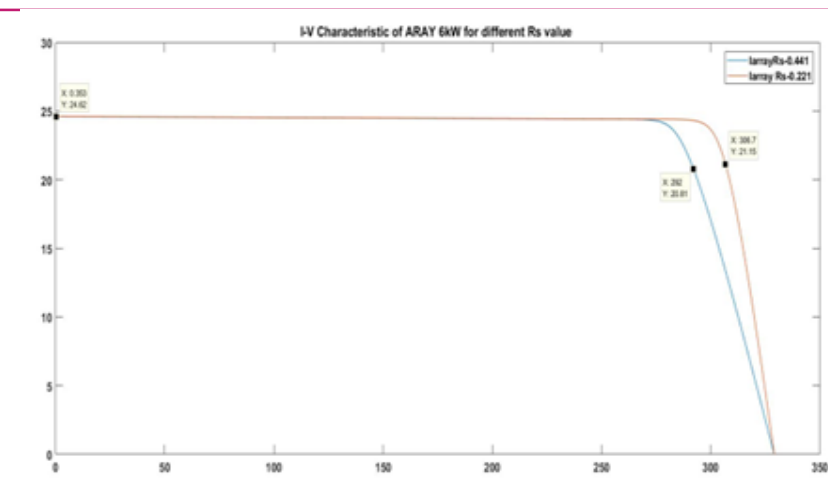

Fig. 14(b). I-V characteristic of PV-Array with different Series Resistance.

taic Array Maximum Power Point Tracking Techniques. IEEE Transactions on Energy Conversion 22(2) 439-449 doi: 10.1109/TEC.2006.874230.

2. Habbati B., Ramdani Y.\& Moulay F. (2014) A detailed modeling of photovoltaic module using MATLAB , NRIAG Journal of Astronomy and Geophysics(3)53-61 http:// dx.doi.org/10.1016/j.nrjag.2014.04.001

3. Kyocera (2009). KC200GT High Efficiency Multi crystal Photovoltaic Module Datasheet. https://www.energy matters.com.au /images/kyocera/KC200GT.pdf

4. Marcelo G.M. (2016). Modelling and Control of Gridconnected Solar Photovoltaic Systems, Renewable Energy - Utilisation and System Integration, Wenping Cao and Yihua Hu, Intech Open, http://dx.doi.org/10.5772/62578

5. https://www.intechopen.com/chapters/50017

6. Motan N., Abu-Khaizaran M. \& Quraan M.(2018). Photovoltaic array modelling and boost-converter controllerdesign for a $6 \mathrm{~kW}$ grid-connected photovoltaic system - DC stage. IEEE International Conference on Environment and Electrical Engineering and IEEE Industrial and Commercial Power Systems Europe. 1-6, doi: 10.1109/EEEIC.20 18.8494003.

7. Nguyen, X.H. \& Nguyen, M.P. (2015). Mathematical modeling of photovoltaic cell/module/arrays with tags in Matlab/Simulink. Environ Syst Res 4(24) https:// doi.org/10.1186/s40068-015-0047-9

8. Natarajan P. \& Ranganath M. (2011). Development of power electronic circuit oriented model of photovoltaic module International Journal of Advanced Engineering Technology 2(4) 118-127.

9. Tsai, Huan-Liang, Ci-Siang, Tu \& Yi-Jie, Su. (2008). Development of generalized photovoltaic model using MATLAB/SIMULINK. Lecture Notes in Engineering and Computer Science. 2173.

10. Tummuru N. R., Mishra M. K. \& Srinivas S.(2015). Dynamic energy management of renewable grid integrated hybrid energy storage system. IEEE Transactions on industrial Electronics, (62)12, 7728-7737. doi: 10.1109/ TIE.2015.2455063

11. Umanand L. (2007). Photovoltaic System Design. CEDTIndian Institute of Science, Banglore, NPTEL course material 